\title{
AC 2007-711: INSTRUCTIONAL STRATEGIES AND TOOLS TO TEACH SIX SIGMA TO ENGINEERING TECHNOLOGY UNDERGRADUATE STUDENTS
}

\section{Sandra Furterer, East Carolina University}

Sandra L. Furterer, Ph.D. is an Assistant Professor in the Industrial Distribution and Logistics

Program in the College of Technology and Computer Science at East Carolina University. Dr. Furterer has extensive industry experience in Quality, Six Sigma, and Information Systems Analysis. Dr. Furterer's research and teaching interests are Six Sigma, Quality Management, Lean Enterprise and Engineering Education.

Sandra Furterer, University of Central Florida 


\title{
Instructional Strategies and Tools to Teach Six Sigma to Engineering Technology Undergraduate Students
}

\begin{abstract}
This paper presents innovative instructional strategies and tools to teach Six Sigma to Engineering Technology undergraduate students. Six Sigma is an improvement methodology focusing on understanding and reducing variation in processes. Many students can easily learn and even apply the basic quality tools in a separate and non-integrated manner, but the real challenge is to help the students learn and apply the tools of Six Sigma in a synthesized way to attain the true power of an integrated approach. This paper will discuss the instructional strategies developed teaching graduate and undergraduate Industrial Engineering students and how the author adapted them to teaching undergraduate Engineering Technology students. Examples of the strategies and tools used to teach the Six Sigma Define-Measure-AnalyzeImprove-Control (DMAIC) methodology and the quality concepts and tools, applied to the students' Six Sigma projects will be discussed. The undergraduate senior-level Six Sigma course combines traditional lectures with experiential learning opportunities where the students apply the DMAIC methodology and Six Sigma tools to real-world projects within the College of Technology and Computer Science (TECS). Sample deliverables and templates from prior students' Six Sigma projects are provided to the students to help them understand the tools and how they integrate to improve the processes. Potential challenges and roadblocks to success are discussed during team mentoring sessions to help the students better apply the problem solving methods. The real-world Six Sigma project examples that the students worked on as part of the experiential learning component include: developing student recruiting plans for the Industrial Distribution and Logistics program, and Computer Science program; streamlining the TECS advising processes to better incorporate voice of the customer requirements; development of processes to assess the college's lab space and inventory and equipment management and control processes; developing processes to help the college's new general engineering department with ABET accreditation. Student feedback of the learning experience, direct observation of the experiential project teams, and work product measures including exams and project reports will be presented to convey the effectiveness of the instructional strategies that were applied.
\end{abstract}

\section{Introduction:}

The Engineer of 2020 report identified several attributes that engineers should acquire in their undergraduate education including: strong analytical skills, communication, leadership, being able to work on multi-disciplinary teams, customerization with a focus on the customer, creativity to synthesize ${ }^{[3]}$. The National Leadership Council for Liberal Education and America's Promise supported by the Association of American Colleges and Universities issued a report that identifies four essential learning outcomes that graduates should possess: 1) a broad base of knowledge across multiple disciplines; intellectual and practical skills such as teamwork and problem-solving; a sense of personal and social responsibility, including ethical reasoning; and experience applying what they learn to real-world problems. ${ }^{[4]}$ Teaching Six Sigma with a 
project experience can help students gain the teamwork and problem-solving skills, and experience applying what they learn to real-world problems. Focusing the projects on community-based organizations can provide a sense of personal and social responsibility. The course also enhances the students' analytical skills, communication, and leadership, being able to work on multi-disciplinary teams, and provide a key focus on the customers' needs.

Six Sigma is an improvement methodology focusing on understanding and reducing variation and defects in processes, identifying and eliminating root causes of problems and improving these processes. Teaching students the DMAIC (Define-Measure-Analyze-Improve-Control) problem solving methodology, along with the statistical and quality tools can help engineers acquire the skills identified in the two reports discussed. Many students can easily learn and even apply the basic quality tools in a separate and non-integrated manner, but the real challenge is to help the students learn and apply the tools of Six Sigma in a synthesized way to attain the true power of an integrated approach. This paper will discuss the instructional strategies developed teaching graduate and undergraduate Industrial Engineering students and how the author adapted them to teaching undergraduate Engineering Technology students. Examples of the instructional strategies and tools used to teach the Six Sigma DMAIC methodology and the quality concepts and tools will be discussed. Student feedback of the learning experience, direct observation of the experiential project teams, and work product measures including exams and project reports will be presented to convey the effectiveness of the instructional strategies that were applied.

\section{Six Sigma Industrial Engineering Graduate Course:}

Total Quality Improvement, ESI 5227, is a graduate-level course currently offered to a mix of graduate and undergraduate students and provides a broad exposure to topics in quality improvement. [1] The course was first enhanced by the author in 2004 to teach the Six Sigma DMAIC (Define-Measure-Analyze-Improve-Control) problem solving methodology and incorporate a real-world six sigma project experiential learning opportunity for the students. It provides learning of the Six Sigma DMAIC problem solving approach and allows the students to perform just-in-time experiential learning opportunities encompassed in a Six Sigma project. The course runs for the 16-week semester and is intended to focus on the development of tools for the management and improvement of quality in community-based organizations. Essential concepts, practices, and methods of modern quality improvement tools are discussed, along with the Six Sigma DMAIC problem solving approach, and critical success factors to team building and teamwork. The Six Sigma team projects are performed by the students applying the DMAIC problem solving approach and appropriate quality tools to help a community-based organization understand and improve their processes and use of technology. Forty-four (44) students took the course in Fall 2005. Twelve (12) of the students were undergraduate seniors, sixteen (16) were Masters students and twelve (12) were doctoral students. The instructor distributed the undergraduate and graduate students across the teams, so that two to three undergraduate students were with three to four graduate students, to enhance mentoring on the teams. The tools are applied within the phases of the DMAIC problem solving methodology, as they are learned in the lecture portion of the course. 


\section{Instructional Strategies:}

There are a wide variety of instructional strategies used in the course, including: 1) traditional face-to-face lectures; 2) real-world Six Sigma experiential learning projects; 3) experienced Black Belt and Master Black Belt mentoring for each team; 4) team-based problem solving, 5) learning from case studies and examples of tools; 6) web-based instructional materials with lecture notes, examples of prior projects with tools, team document repository for document sharing, discussion areas for asynchronous meetings, and on-line quizzes and exams for assessment of learning.

Traditional Face-to-Face Lectures:

The course consists of a lecture component that uses PowerPoint presentations to teach the students the principles and tools of Six Sigma and the DMAIC problem-solving approach in a traditional face-to-face lecture setting. The weekly class is composed of two hours of lecture and one hour of in-class team-based problem solving and team-building activities.

Real-world Six Sigma Experiential Learning Projects:

The experiential learning component consists of students working on teams of five to seven students on a real-world, community-based Six Sigma project. The instructor worked with university and community contacts to identify opportunities where improvement was needed. Many of the projects were with units at the university, including the Department of Industrial Engineering and Management Systems, the College of Engineering and Computer Science, Academic Affairs, the Office of Fraternity and Sorority Life, and outside community-oriented organizations such as a child advocacy center, a local high school, and a financial services organization. The teams apply the DMAIC and Six Sigma tools within the project throughout the semester. The students perform the Define, Measure, and Analyze phases of the DMAIC problem solving approach and suggest process improvement and control recommendations that allow the project sponsors to Implement the recommendations and Control mechanisms. Each student spends about 8 to 10 hours per week outside of class on the Six Sigma project activities, for a total resource and mentor effort of approximately 5200 hours across the 16-week semester. Eight different Six Sigma projects were completed during the semester.

Experienced Black Belt and Master Black Belt Mentoring:

Each team has an experienced and certified Six Sigma Black Belt mentor that attends project meetings and helps the students better apply the six sigma tools and to identify which tools they should apply based on the needs of the project. Professionals from the local ASQ professional chapter perform Six Sigma Black Belt coaching and knowledge transfer for each of the student teams. They also provide project management and meeting effectiveness insights. The Black Belts provide guidance and feedback to the students by observing their problem solving activities and meetings, and reviewing their project reports. The course instructor, the principle author of this paper, served as the Master Black Belt that provides mentoring to all of the teams.

Team-based Problem Solving:

The team-based problem solving includes the students working together with the client 
organization to apply the DMAIC problem solving methodology. The students develop the project charter which includes the project objectives and goals. They create project work plans and timelines, and assign roles and responsibilities across the team members. One of the students that has had prior team leadership experience is assigned as the team leader by the instructor. The team leader will typically have Green Belt level experience and certification and have worked on at least one other Six Sigma project. The team leader manages the team, and ensures that project commitments are met. The teams develop customer surveys and/or hold focus groups with the clients to understand their requirements, the processes to be improved, and problems with the processes. The team-based problem solving is vital to learning and being able to apply the vast array of tools of the Six Sigma tool set within the sixteen weeks available in the semester. The complexity of the processes to be improved also encourages the use of teambased problem solving.

Learning From Prior Case Studies and Examples of Tools:

Case study examples of prior classes" "real world" application of Six Sigma tools were presented to the students to enhance their understanding of the tools. A detailed course map was also developed by the instructor to help the students understand the tools that are typically used during certain phases of the DMAIC methodology.

Web-based Instructional Materials:

WebCT was used to provide web-based instructional materials to the students. The Powerpoint lecture notes were provided to the students on-line prior to the lectures. Selected examples of prior Six Sigma projects with the tools used by the teams were provided on the web site for students to view and download. The teams had a group area on the website where they had a document repository available for document sharing and easy review and updating, discussion areas for asynchronous meetings, and emailing available. The web site enabled assessment of the students' learning through on-line quizzes and exams. The students' grades and assignments were also posted on the WebCT course site. The students share knowledge across the teams by uploading their presentations and reports to a shared website.

\section{Effectiveness of Learning:}

The instructor assessed the effectiveness of the students' learning in the Six Sigma course in four ways: 1) survey of the Six Sigma project experiential learning experience, 2) direct observation of the team problem solving effort, 3) work product measures of how well the students learned and applied the Six Sigma methodology and tools, and 4) survey of students' overall assessment of the instructor.

The students completed a survey to assess the value of the Six Sigma projects. There were fifty questions on the survey that the instructor had developed to assess the success of the Six Sigma projects, four of the questions were used to assess whether the students' believed that the Six Sigma project was a valuable learning experience, shown in table 1. 
Table 1: Assessment of Effectiveness of Learning:

\begin{tabular}{|l|l|l|l|l|l|}
\hline \multicolumn{1}{|c|}{ Question } & $\begin{array}{c}\text { \% Rating } \\
\text { in } \\
\text { Strongly } \\
\text { Disagree }\end{array}$ & $\begin{array}{c}\text { \% Rating } \\
\text { in } \\
\text { Disagree }\end{array}$ & $\begin{array}{c}\text { \% Rating } \\
\text { in Neither } \\
\text { Agree nor } \\
\text { Disagree }\end{array}$ & $\begin{array}{c}\text { \% Rating } \\
\text { in Agree }\end{array}$ & $\begin{array}{c}\text { \% Rating } \\
\text { in } \\
\text { Strongly } \\
\text { Agree }\end{array}$ \\
\hline $\begin{array}{l}\text { The project team members' } \\
\text { personal and profession goals } \\
\text { were successfully met. }\end{array}$ & $0 \%$ & $0 \%$ & $2 \%$ & $14 \%$ & $84 \%$ \\
\hline $\begin{array}{l}\text { My experience on the Six Sigma } \\
\text { project was worthwhile. }\end{array}$ & $0 \%$ & $0 \%$ & $2 \%$ & $7 \%$ & $91 \%$ \\
\hline $\begin{array}{l}\text { I believe that my experience on } \\
\text { the Six Sigma project will help } \\
\text { me in my profession. }\end{array}$ & $0 \%$ & $0 \%$ & $2 \%$ & $7 \%$ & $91 \%$ \\
\hline $\begin{array}{l}\text { Overall, the Six Sigma project } \\
\text { that I was associated with was a } \\
\text { success. }\end{array}$ & $0 \%$ & $0 \%$ & $2 \%$ & $14 \%$ & $83 \%$ \\
\hline
\end{tabular}

The instructor and the Black Belt mentors directly observed the students working on the teams during project planning and problem solving working meetings. The Black Belt and instructors did provide feedback, which should have altered their behavior, and was designed to enhance their learning.

The student teams' learning was also assessed based on phase reports and presentations. A report and presentation was completed at the end of the Define, Measure, and Analyze phases, as well as at the end of the semester, summarizing the entire problem solving effort. It included plans for improvement and control. The reports were evaluated on both format and content, and how well the students applied the Six Sigma and Lean tools to identify and solve the process problems. The client sponsors attended the report presentations, received the reports, and provided feedback from a content perspective and how helpful the findings and recommendations were to their organizations and to solving the problems. The overall average grade on a 100 point scale for the phase reports was $92 \%$, with a range of $86 \%$ to $96 \%$. The grades per team and phase, along with the average and standard deviation per phase and team are presented in table 2 . 
Table 2: Work Product Assessment Grade Results by Team and Phase

\begin{tabular}{|r|r|r|r|r|r|r|r|}
\hline \multicolumn{1}{|c|}{ Team } & \multicolumn{1}{|c|}{ Define } & Measure & Analyze & \multicolumn{1}{c|}{ Final } & Average & $\begin{array}{l}\text { Standard } \\
\text { Deviation }\end{array}$ \\
\hline 1 & 86 & 72 & 97 & 88 & 86 & 10.34 \\
\hline 2 & 91 & 93 & 100 & 98 & 96 & 4.20 \\
\hline 3 & 89 & 94 & 100 & 90 & 93 & 4.99 \\
\hline 4 & 93 & 81 & 98 & 100 & 93 & 8.52 \\
\hline 5 & 90 & 81 & 103 & 91 & 91 & 9.03 \\
\hline 6 & 89 & 81 & 101 & 94 & 91 & 8.42 \\
\hline 7 & 99 & 83 & 99 & 97 & 95 & 7.72 \\
\hline 8 & 98 & 85 & 92 & 94 & 92 & 5.44 \\
\hline AVERAGE: & 92 & 84 & 99 & 94 & 92 & \\
\hline $\begin{array}{r}\text { STANDARD } \\
\text { DEVIATION: }\end{array}$ & 4.55 & 7.11 & 3.28 & 4.17 & & \\
\cline { 1 - 3 }
\end{tabular}

The university's students' evaluation of the instructor survey was used to understand the 'overall assessment of the instructor. The instructor received $\mathbf{9 2 \%}$ of the ratings for this question in the positive ratings (excellent, very good, and good). This demonstrates that the students' were satisfied with the instructors' ability to instruct the students, and demonstrates student satisfaction in the learning experience.

\section{Undergraduate Engineering Technology Six Sigma Course:}

The instructor enhanced an undergraduate engineering technology quality assurance course in Fall 2006 to provide a Six Sigma experiential learning project, similar to the graduate course already discussed. Thirty one undergraduate students took the course in this format in Fall 2006. Twenty one of the students were seniors, eight were juniors and two were sophomores. They were all engineering technology students across a variety of engineering technology programs, including industrial distribution and logistics (16 students), design (6 students), and industrial engineering technology (9 students). The course was a 15-week semester course, including a lecture component, 75 minutes, twice a week, as well as the team-based project experience. The lecture component included time for the instructor to meet with the teams to provide the Master Black belt mentoring to help the students better understand and apply the Six Sigma tools. However, the instructor did not have access to a cadre of experienced quality professionals in Black Belt roles for the team mentoring. The Six Sigma team projects included the students performing the Define, Measure and Analyze phases, and providing recommendations for the Improve and Control phases. Six project teams consisted of from 4 to 6 members each. One student, due to taking the course via distance learning, worked on a project individually with his family-owned business. The course is designed to provide the students with an understanding of the strategic importance of Quality programs, provide the students with a basic understanding of Six Sigma techniques which are utilized in improvement efforts, and to provide an understanding of the use of Six Sigma as a management framework for the entire enterprise. ${ }^{\text {[2] }}$ There were differences in the depth of the material and the number of topics that could be covered in this course compared to the industrial engineering graduate level course previously discussed. A much longer portion of this course had to be dedicated to reviewing, and for some students learning, the basic statistical concepts. Unfortunately there was then not a lot of course time 
available for some of the Six Sigma Green Belt body of knowledge including statistical process control and design of experiments. In the graduate industrial engineering program, the students generally took a separate statistical process control course as well as a separate design of experiments course. The undergraduates that took the industrial engineering course also had a separate course where linear regression and analysis of variance was taught. The engineering technology students only had the one business level statistics course which included: sampling and probability distributions, measures of central tendency and dispersion, hypothesis testing, Chi-square, and regression.

\section{Instructional Strategies:}

The instructor applied several of the instructional strategies used in the industrial engineering graduate course previously taught at another university, and enhanced some of the strategies to adapt to the differences in the preparation of the engineering technology students. The engineering technology students had only one business statistics course, and many of them had taken it several years prior to taking this course. They also had not participated in a structured problem solving experience trying to solve an unstructured problem in the past. The students had worked on teams in the past, and rated themselves, on average, a seven on a 1 to 10 point scale, regarding their amount of team experience prior to the course. The instructional strategies applied in this course included: 1) traditional face-to-face lectures; 2) real-world Six Sigma experiential learning projects; 3) the instructor as an experienced Master Black Belt mentor across all of the teams; 4) team-based problem solving; 5) learning from case studies and examples of tools; 6) web-based instructional materials with lecture notes, examples of prior projects with tools, team document repository for document sharing, discussion areas for asynchronous meetings, and on-line quizzes and exams for assessment of learning; 7) Six Sigma tool templates to help synthesize application across tools and the DMAIC and provide better application of individual tools. The major differences in instructional strategies used in this undergraduate engineering technology course versus the graduate level industrial engineering course was to provide the tool templates that helped the students better synthesize use across the tools and phases, and provided specific guidance in use of the tools.

Traditional Face-to-Face Lectures:

The course consists of a lecture component that uses PowerPoint presentations to teach the students the principles and tools of Six Sigma and the DMAIC problem-solving approach in a traditional face-to-face lecture setting. The weekly class is composed of two, one and a quarter hours of lecture each week. This format did not provide a great deal of time to spend in in-class team-based solving and team-building activities, so the instructor did meet with many of the teams outside of class to providing mentoring on the tools and problem solving techniques.

Real-world Six Sigma Experiential Learning Projects:

The experiential learning component consisted of students working on teams of four to six students on a real-world, university-based Six Sigma project. The instructor worked with the university contacts to identify opportunities where improvement was needed. All of the projects were with departments within the College of Technology and Computer Science (TECS). The 
Dean strongly supported continuous improvement within the college. The departments included: the Advising Center within the college, the newly formed Engineering Department, the Technology Systems Department, the Computer Science Department, and college-wide efforts.

The teams applied the DMAIC and Six Sigma tools within the project throughout the semester. The students performed the Define, Measure, and Analyze phases of the DMAIC problem solving approach and suggest process improvement and control recommendations that allow the project sponsors to Implement the recommendations and Control mechanisms. Each student spent about 8 to 10 hours per week outside of class on the Six Sigma project activities.

Following in table 3 are the project titles and objectives for the Six Sigma projects that were completed in the class during the Fall 2006 semester.

Table 3: Six Sigma Projects Titles and Objectives

1) Advising Center Process Improvement. The objective of this project was to develop processes for advising of students for the College of Technology and Computer Science Advising Center.

2) Department of Engineering ABET Accreditation Process Definition. The objective of this project was to design streamlined and efficient processes that can help the department of Engineering develop processes for preparing for their ABET accreditation, including a process for program assessment.

3) College of Technology and Computer Science Lab Space Assessment and Utilization Process Design. The objective of this project was to design streamlined and efficient processes to assess, assign and optimize utilization of labs across the college. It was to include collection of the voice of the customer to understand the teaching lab needs of the students and faculty.

4) Department of Computer Science Recruiting Process Design. The objective of this project was to design streamlined and efficient processes for recruiting students from high schools, including interfacing with high school guidance counselors for the computer science program.

5) Industrial Distribution and Logistics (IDIS) Program Recruiting Process Design. The objective of this project was to design student recruiting processes that will enhance the recruiting efforts for the IDIS program both internally and external to the university.

6) College of Technology and Computer Science (TECS) Lab Process Design. The objective of this project was to design streamlined and efficient processes for managing equipment and inventory in the TECS Labs. The project included defining processes for inventorying and controlling equipment and supplies.

7) Purchasing Scheduling Process Design. The objective of this project was to design processes for scheduling of purchased parts and components for the business to be able to better manage and control quality and delivery of products for the business. This project was worked on by only one student.

\section{Experienced Master Black Belt Mentoring:}

The course instructor, the principle author of this paper, served as the Master Black Belt that provides mentoring to all of the teams. Each team did not have an experienced Six Sigma Black 
Belt mentor. This seriously hindered the ability to provide for customized and detailed mentoring for the students on the Six Sigma tools. The instructor also spent a great deal of time outside of the course meeting with the students to help them with the projects. Fortunately some of the project sponsors provided some guidance on problem solving and project management skills with the student teams.

Team-based Problem Solving:

The team-based problem solving includes the students working together with the client organization to apply the DMAIC problem solving methodology. The students develop the project charter which includes the project objectives and goals. They create project work plans and timelines, and assign roles and responsibilities across the teams. One of the students that have had prior team leadership experience is assigned as the team leader by the instructor. The team leader manages the team, and ensures that project commitments are met. The teams develop customer surveys and/or hold focus groups with the clients to understand their requirements, the processes to be improved, and problems with the processes. The team-based problem solving is vital to learning and being able to apply the vast array of tools within the Six Sigma tool set within the semester. The complexity of the processes to be improved also encourages the use of team-based problem solving.

Learning From Prior Case Studies and Examples of Tools:

Case study examples of prior "real world" application of Six Sigma tools were presented to the students to enhance their understanding of the tools. One complete project from the graduate level industrial engineering Six Sigma course was used to provide examples of the tools and DMAIC phase reports. A detailed course map was also used in this course to help the students understand the tools that are typically used during certain phases of the DMAIC methodology, shown in table 4. 
Table 4: Course Mapping of Six Sigma Phase and Tools Typically Applied

\begin{tabular}{|c|c|c|c|c|}
\hline DEFINE & MEASURE & ANALYZE & IMPROVE & CONTROL \\
\hline $\begin{array}{ll}\text { - } & \text { Brainstorming } \\
\text { - } & \text { Nominal Group } \\
\text { - } & \text { Project charter } \\
\text { - } & \text { Work plan } \\
\text { - } & \text { Responsibilities } \\
\text { - } & \text { SIPOtrix } \\
\text { - } & \text { QFD } \\
\text { - } & \text { SWOT } \\
\text { - } & \text { Customer } \\
& \text { stakeholder } \\
\text { - } & \text { Resistance to } \\
\text { change } \\
\text { - } \\
\text { assessment } \\
\text { - } \quad \text { rules ground } \\
\text { - } \\
\text { planning } \\
\text { Meeting } \\
\text { feedback } \\
\text { questionnaire } \\
\text { Items for } \\
\text { Resolutions } \\
\text { Log }\end{array}$ & $\begin{array}{ll}\text { - } & \text { Multi-voting } \\
\text { - } & \text { Process flow } \\
\text { - } & \text { } \text { Bencharts } \\
\text { - } & \text { Check sheets } \\
\text { - } & \text { Surveys } \\
\text { - } & \text { Interviewing } \\
\text { - } & \text { Focus Groups } \\
\text { - } & \text { Waste } \\
& \text { Identification } \\
& \text { and elimination } \\
\text { - } & \text { Standardization } \\
& \text { of operations } \\
\text { - } & \text { Good } \\
& \text { housekeeping } \\
\text { - } & \text { 5S's } \\
\text { - } & \text { Pareto analysis } \\
\text { - } & \text { Cause \& Effect } \\
\text { - } & \text { CTQs } \\
\text { - } & \text { SPC } \\
\text { - } & \text { Histograms } \\
\text { - } & \text { Performance } \\
\text { - } & \text { metrics } \\
\text { - } & \text { Capability } \\
& \text { diagrams } \\
\text { Benchmarking }\end{array}$ & 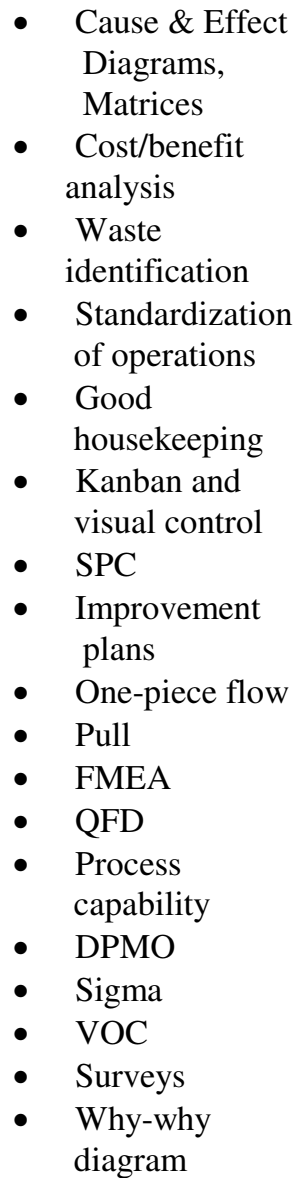 & $\begin{array}{ll}\text { - } & \text { Cost/benefit } \\
\text { - } & \text { Imalysis } \\
\text { Improvement } & \text { plans } \\
\text { - } & \text { Standardized } \\
\text { procedures } & \text { Training, } \\
\text { - } & \text { pull, one } \\
\text { piece flow } \\
\text { - } \\
\text { Action Plans } \\
\text { Results of } \\
\text { performance } \\
\text { - Future } \\
\text { process } \\
\text { flows }\end{array}$ & $\begin{array}{ll}\text { - } & \text { SPC } \\
\text { - } & \text { One-piece } \\
& \text { flow } \\
\text { - } & \text { Kanban } \\
& \text { and visual } \\
& \text { control } \\
\text { - } & \text { Continuous } \\
\text { improvement } & \text { and Kaizen } \\
\text { - } & \text { Control } \\
& \text { Plans } \\
\text { - } & \text { Training } \\
& \text { Plans }\end{array}$ \\
\hline
\end{tabular}

Web-based Instructional Materials:

Blackboard was used to provide web-based instructional materials to the students. The Powerpoint lecture notes were provided to the students on-line prior to the lectures. Selected examples of prior Six Sigma projects with the tools used by the teams were provided on the web site for students to view and download. The teams had a group area on the website where they had a document repository available for document sharing and easy review and updating, discussion areas for asynchronous meetings, and emailing available. The web site enabled assessment of the students' learning through on-line exams. The students' grades and assignments were also posted on the Blackboard course site. The students share knowledge across the teams by uploading their presentations and reports to a shared website.

Six Sigma Tool Templates:

Six Sigma Tool Templates developed by the instructor were used to help the students synthesize information across tools and the phases of the DMAIC problem solving approach, and to provide better application of individual tools. The majority of the templates were provided for the 
Define and Measure phases, to help properly scope the project and collect data on the voice of the customer and the voice of the process. The templates included a project charter, a responsibility matrix, team ground rules, team roles and responsibilities, project work plan, a customer-stakeholder analysis, stakeholder commitment matrix, communication planning worksheet, project risk analysis matrix, items for resolution log, meeting agenda template, meeting feedback questionnaire, criteria prioritization matrix, Failure Mode and Effect Analysis worksheet, Cause and Effect matrix, Quality Function Deployment template, data collection plan template, and CTQ-Factor-Operational Definition-Metric-Target Mapping matrix.

Some examples of the Six Sigma Tool Templates are included: data collection plan, and the CTQ-Factor-Operational Definition-Metric-Target Mapping matrix. A data collection plan template helps the students map the Critical to Quality Characteristics to the metrics, the data collection mechanism, the analysis mechanism, the sampling plan and important sampling instructions. The Critical to Quality Characteristics (CTQs) define, from a customers' perspective, what they perceive as critical to the quality of the process, product or service. The metric provides a measurement of the CTQs. The CTQs are extracted from the voice of the customer data, including surveys, focus groups, interviews, and benchmarking. The data collection mechanism provides information on how the team members will collect data to understand the CTQs. The analysis mechanism helps the students understand how they will analyze the data collected on the CTQs. The sampling plan provides details on how the data will be sampled. The sampling instructions provide details of how to sample the data, and helps provide consistency across the various team members collecting the data. Table 5 presents a sample Data Collection Plan template.

Table 5: Data Collection Plan Template

\begin{tabular}{|c|c|c|c|c|c|}
\hline CTQ & Metric & $\begin{array}{c}\text { Data collection } \\
\text { mechanism }\end{array}$ & $\begin{array}{l}\text { Analysis } \\
\text { mechanism }\end{array}$ & Sampling plan & $\begin{array}{c}\text { Sampling } \\
\text { instructions }\end{array}$ \\
\hline $\begin{array}{l}\text { Define current } \\
\text { process }\end{array}$ & $\begin{array}{l}\text { Determine } \\
\text { process }\end{array}$ & $\begin{array}{l}\text { Lab tour, } \\
\text { interview }\end{array}$ & $\begin{array}{l}\text { Process } \\
\text { flowchart }\end{array}$ & $\begin{array}{l}\text { Number of } \\
\text { interviews, } 8 \\
\text { dept. heads } \\
\end{array}$ & $\begin{array}{l}\text { List of questions } \\
\text { to ask }\end{array}$ \\
\hline Safety & $\begin{array}{l}\text { Broken } \\
\text { equipment } \\
\text { Number of } \\
\text { accidents (days } \\
\text { since last } \\
\text { accident) }\end{array}$ & $\begin{array}{l}\text { Interview } \\
\text { Accident logs } \\
\text { Visual } \\
\text { inspection } \\
\text { Benchmarking } \\
\text { Review safety } \\
\text { regulations }\end{array}$ & $\begin{array}{l}\text { Statistics, mean, } \\
\text { standard dev, } \\
\text { Compared to } \\
\text { benchmarking, } \\
\text { Histogram }\end{array}$ & $\begin{array}{l}\text { Review safety } \\
\text { regulations and } \\
\text { lab data } \\
\text { Students } \\
\text { Teachers }\end{array}$ & Instructions. \\
\hline Ergonomics & $\begin{array}{l}\text { Level of student } \\
\text { comfort }\end{array}$ & $\begin{array}{l}\text { Survey } \\
\text { Market research }\end{array}$ & $\begin{array}{l}\text { Rankings, } \\
\text { ratings in each } \\
\text { category, } \\
\text { Chi-square test }\end{array}$ & 50 people & $\begin{array}{l}\text { Lab students - } \\
\text { instructions }\end{array}$ \\
\hline
\end{tabular}

The CTQ-Factor-Operational Definition-Metric-Target Mapping is used to map the Critical to Quality Characteristics to the causal factors of the CTQs. The factors are identified through the data collection and voice of the process analysis. Operational Definitions are developed that clearly define the CTQ so that it can be measured. The metric is how the CTQ will be measured, 
to ensure that the CTQ is met. The target is the desired level related to the metric and CTQ. Table 6 presents a sample CTQ-Factor-Operational Definition-Metric-Target Mapping template.

Table 6: CTQ - Factor-Operational Definition-Metric-Target Mapping

\begin{tabular}{|c|c|c|c|c|}
\hline CTQ & Factors & $\begin{array}{c}\text { Operational } \\
\text { Definition }\end{array}$ & Metric & Target \\
\hline $\begin{array}{l}\text { \% Minorities } \\
\text { enrolled in } \\
\text { Advanced Placement } \\
\text { classes }\end{array}$ & $\begin{array}{l}\text { Encouragement by } \\
\text { guidance counselors } \\
\text { Open Access to AP classes }\end{array}$ & $\begin{array}{l}\text { Number of students } \\
\text { within each racial } \\
\text { classification divided by } \\
\text { the total number of } \\
\text { students }\end{array}$ & $\begin{array}{l}\% \text { minorities } \\
\text { enrolled in AP } \\
\text { classes }\end{array}$ & $\begin{array}{l}\text { Comparable to school } \\
\text { population by racial } \\
\text { classification }\end{array}$ \\
\hline $\begin{array}{l}\% \text { Lower } \\
\text { Socioeconomic }\end{array}$ & $\begin{array}{l}\text { Encouragement by } \\
\text { guidance counselors } \\
\text { Open Access to AP classes }\end{array}$ & $\begin{array}{l}\text { Number of students that } \\
\text { receive free or reduced } \\
\text { lunch divided by the total } \\
\text { number of students }\end{array}$ & $\begin{array}{l}\% \text { lower } \\
\text { socioeconomic }\end{array}$ & $\begin{array}{l}\text { Comparable to school } \\
\text { population by } \\
\text { socioeconomic } \\
\text { classification }\end{array}$ \\
\hline $\begin{array}{l}\text { Course topics } \\
\text { covered }\end{array}$ & $\begin{array}{l}\text { Teacher experience } \\
\text { Student level }\end{array}$ & $\begin{array}{l}\text { Number of courses } \\
\text { included by class that are } \\
\text { defined by national } \\
\text { standards to be covered } \\
\text { in the course }\end{array}$ & $\begin{array}{l}\text { Number courses } \\
\text { covered }\end{array}$ & All \\
\hline Teacher experience & $\begin{array}{l}\text { Experience teaching } \\
\text { Experience teaching AP } \\
\text { courses }\end{array}$ & $\begin{array}{l}\% \text { of teachers with } \\
\text { experience teaching AP } \\
\text { courses for more than } \\
\text { one year }\end{array}$ & $\begin{array}{l}\% \text { by teachers } \\
\text { teaching AP } \\
\text { courses }\end{array}$ & $100 \%$ \\
\hline AP Class grades & $\begin{array}{l}\text { Teacher experience } \\
\text { Student level } \\
\text { Student motivation }\end{array}$ & $\begin{array}{l}\% \text { of student grades } \\
\text { above } \mathrm{B} \text { in each class }\end{array}$ & $\%$ grades above $\mathrm{B}$ & $100 \%$ \\
\hline AP Test grades & $\begin{array}{l}\text { Teacher experience } \\
\text { Student level } \\
\text { Student motivation }\end{array}$ & $\begin{array}{l}\% \text { of tests receiving over } \\
3 \text { on AP tests }\end{array}$ & $\begin{array}{l}\% \text { grade of test } \\
\text { over } 3\end{array}$ & $100 \%$ \\
\hline
\end{tabular}

\section{Effectiveness of Learning:}

The instructor assessed the effectiveness of the students' learning in the Six Sigma course in four ways: 1) survey of the Six Sigma project experiential learning experience, 2) direct observation of the team problem solving effort, and 3) work product measures of how well the students learned and applied the Six Sigma methodology and tools, and 4) survey of students' opinion of instruction.

The students completed a similar survey as in the prior class to assess the value of the Six Sigma projects. The same four questions were used to assess whether the students' believed that the Six Sigma project was a valuable learning experience, shown in table 7. 
Table 7: Assessment of Effectiveness of Learning:

\begin{tabular}{|l|l|l|l|l|l|}
\hline \multicolumn{1}{|c|}{ Question } & $\begin{array}{c}\text { \% Rating } \\
\text { in } \\
\text { Strongly } \\
\text { Disagree }\end{array}$ & $\begin{array}{c}\text { \% Rating } \\
\text { in } \\
\text { Disagree }\end{array}$ & $\begin{array}{c}\text { \% Rating } \\
\text { in Neither } \\
\text { Agree nor } \\
\text { Disagree }\end{array}$ & $\begin{array}{c}\text { \% Rating } \\
\text { in Agree }\end{array}$ & $\begin{array}{c}\text { \% Rating } \\
\text { in } \\
\text { Strongly } \\
\text { Agree }\end{array}$ \\
\hline $\begin{array}{l}\text { The project team members' } \\
\text { personal and profession goals } \\
\text { were successfully met. }\end{array}$ & $0 \%$ & $0 \%$ & $18 \%$ & $73 \%$ & $9 \%$ \\
\hline $\begin{array}{l}\text { My experience on the Six Sigma } \\
\text { project was worthwhile. }\end{array}$ & $5 \%$ & $14 \%$ & $14 \%$ & $27 \%$ & $41 \%$ \\
\hline $\begin{array}{l}\text { I believe that my experience on } \\
\text { the Six Sigma project will help } \\
\text { me in my profession. }\end{array}$ & $0 \%$ & $9 \%$ & $14 \%$ & $45 \%$ & $32 \%$ \\
\hline $\begin{array}{l}\text { Overall, the Six Sigma project } \\
\text { that I was associated with was a } \\
\text { success. }\end{array}$ & $0 \%$ & $9 \%$ & $32 \%$ & $41 \%$ & $18 \%$ \\
\hline
\end{tabular}

The instructor directly observed the students working on the teams during project planning and problem solving working meetings. The instructor provided feedback, which should have altered their behavior, and was designed to enhance their learning.

The student teams' learning was also assessed based on phase reports and presentations. A report and presentation was completed at the end of the Define, Measure, and Analyze phases, as well as at the end of the semester, summarizing the entire problem solving effort. It included plans for improvement and control. The reports were evaluated on both format and content, and how well the students applied the Six Sigma and Lean tools to identify and solve the process problems. The client sponsors attended the report presentations, received the reports, and provided feedback from a content perspective and how helpful the findings and recommendations were to their organizations and to solving the problems. The overall average grade on a 100 point scale for the phase reports was $84 \%$, with a range of $73 \%$ to $93 \%$. The grades per team and phase, along with the average and standard deviation per phase and team are presented in table 8 . 
Table 8: Work Product Assessment Grade Results by Team and Phase

\begin{tabular}{|c|c|c|c|c|c|c|}
\hline Team & Define & Measure & Analyze & Final & Average & $\begin{array}{l}\text { Standard } \\
\text { Deviation }\end{array}$ \\
\hline 1 & 85 & 44 & 76 & 85 & 73 & 19.47 \\
\hline 2 & 91 & 80 & 57 & 84 & 78 & 14.72 \\
\hline 3 & 91 & 89 & 93 & 88 & 90 & 2.22 \\
\hline 4 & 93 & 67 & 79 & 93 & 83 & 12.54 \\
\hline 5 & 72 & 74 & 96 & 88 & 83 & 11.47 \\
\hline 6 & 96 & 86 & 93 & 95 & 93 & 4.51 \\
\hline 7 & 97 & 86 & 78 & 95 & 89 & 8.76 \\
\hline AVERAGE: & 89 & 75 & 82 & 90 & 84 & \\
\hline $\begin{array}{l}\text { STANDARD } \\
\text { DEVIATION: }\end{array}$ & 8.58 & 15.75 & 13.68 & 4.61 & 7.16 & \\
\hline
\end{tabular}

The university's students' opinion of the instructor survey were used to understand the 'Overall, Effective' assessment of the instructor. The instructor received $\mathbf{8 0 \%}$ of the ratings for this question in the positive ratings (5, 6, 7 on the Strongly Agree end of the rating scale). This demonstrates that the students were somewhat satisfied with the instructors' ability to instruct the students, and with their learning experience.

\section{Results Comparison of Teaching Effectiveness Between the Two Courses:}

The author compared the teaching effectiveness between the two courses based on the 1) survey of the Six Sigma project experiential learning experience results, 2) the direct observation of the team problem solving effort, and 3) the work product measures. The students' opinion of the instructor surveys were different for the two universities, so these numbers may not be comparable due to different questions being used, so they were not compared.

Survey of the Six Sigma project experiential learning experience:

For the four questions to survey the students' perception of the Six Sigma project experiential learning experience, there was a significant difference between the results for the two classes. Comparing the percentages in the ratings using a Chi-square test, between the two classes, there was a statistically significant difference between the two classes for each question. Table 9 shows the Chi-square values and the p-values. 
Table 9: Statistical Results by Survey Question between each class

\begin{tabular}{|l|l|l|l|}
\hline \multicolumn{1}{|c|}{ Survey Question } & Chi-square value & P-value & \multicolumn{1}{|c|}{$\begin{array}{c}\text { Statistically } \\
\text { Significant } \\
\text { Difference? }\end{array}$} \\
\hline $\begin{array}{l}\text { 1) The project team members' } \\
\text { personal and professional goals } \\
\text { were successfully met. }\end{array}$ & 99.795 & $\mathrm{p}=0, \mathrm{DF}=2$ & Yes \\
\hline $\begin{array}{l}\text { 2) My experience on the Six Sigma } \\
\text { project was worthwhile. }\end{array}$ & 58.701 & $\mathrm{p}=0, \mathrm{DF}=4$ & Yes \\
\hline $\begin{array}{l}\text { 3) I believe that my experience on } \\
\text { the Six Sigma project will help me in } \\
\text { my profession. }\end{array}$ & 74.07 & $\mathrm{p}=0, \mathrm{DF}=3$ & Yes \\
\hline $\begin{array}{l}\text { 4) Overall, the Six Sigma project } \\
\text { that I was associated with was a } \\
\text { success. }\end{array}$ & 90.554 & $\mathrm{p}=0, \mathrm{DF}=3$ & Yes \\
\hline
\end{tabular}

Direct Observation of the Problem Solving Method:

The instructor saw a great difference between the problem solving abilities of the engineering technology students, and their grasp of and ability to apply the Six Sigma tools compared to the Industrial Engineering students. The engineering technology students had a much more difficult time with problem solving, applying the DMAIC methodology and the Six Sigma tools. Even when comparing only the undergraduate students, the industrial engineering students generally were better problem solvers.

Work Product Measures:

There was a significant difference in the grades received on the Six Sigma reports work products for the students in the two classes. A t-test was performed that compared the grades received on the reports for each class. There was an $8.13 \%$ difference in grades between the two classes, with a t-value of 3.03, with a p-value of 0.004 with 42 degrees of freedom. The Industrial Engineering students had an average grade of $92 \%$ and the Engineering Technology students had an average $84 \%$.

\section{Analysis of Shortcomings and Suggested Improvements:}

The assessment results for the Engineering Technology undergraduate Six Sigma course showed less student satisfaction, and less effective learning compared to the graduate course. Some of this is probably related to the Engineering Technology students not having as extensive experience in unstructured problem solving, and not as much statistical preparation prior to the course. Many of the students were extremely intimidated by the amount and level of work to be done on the project. This could be related to the nature of the students, and the instructor not 
clearly setting the expectations of the amount of work that needed to be done during the semester on the project. It was also extremely difficult for the instructor to be the only Black Belt mentor, and subsequently may not have provided enough coaching for the students on the tools and methodology.

The instructor decided to slightly change the instructional strategy around the real world Six Sigma project during the Spring 2007 semester. Instead of the students working on a "from scratch" new real world Six Sigma project, the instructor is using a prior project from the graduate level Six Sigma course. She is providing the background to the problem, and the data that was collected. The students will work in teams and solve the problem applying the Six Sigma DMAIC methodology and tools, just not collect the data or have a real client to talk to. Although they don't get the interaction with a real project sponsor and customers, they do get the advantage of real data and an actual problem that needed to be solved. The students will write Define, Measure, Analyze, and a Final Report including the Improve and Control recommendations, as well as prepare and deliver one of the phase report presentations. This provides time to prepare the students in the foundations of statistics, and the DMAIC methodology, while providing an "almost" nuts to bolts real world Six Sigma project experience.

\section{Conclusions:}

Real-world experiential learning is a valuable way for students to learn problem solving skills, including the Six Sigma tools and the DMAIC problem solving approach. The instructional strategies applied in a graduate-level Industrial Engineering (IE) student Six Sigma course were more effective in helping the IE students learn and apply the Six Sigma methodology. The instructional strategies applied were: 1) traditional face-to-face lectures; 2) real-world Six Sigma experiential learning projects; 3) experienced Black Belt and Master Black Belt mentoring for each team; 4) team-based problem solving, 5) learning from case studies and examples of tools; 6) web-based instructional materials with lecture notes, examples of prior projects with tools, team document repository for document sharing, discussion areas for asynchronous meetings, and on-line quizzes and exams for assessment of learning.

Similar instructional strategies were also applied in an undergraduate engineering technology course, such as: 1) traditional face-to-face lectures; 2) real-world Six Sigma experiential learning projects; 3) the instructor as an experienced Master Black Belt mentor across all of the teams; 4) team-based problem solving; 5) learning from case studies and examples of tools; 6) web-based instructional materials with lecture notes, examples of prior projects with tools, team document repository for document sharing, discussion areas for asynchronous meetings, and on-line quizzes and exams for assessment of learning; 7) Six Sigma tool templates to help synthesize application across tools and the DMAIC and provide better application of individual tools.

The industrial engineering students were more satisfied with the experiential learning Six Sigma project experience than the engineering technology students were. The industrial engineering students had a better grasp of the material, and were better able to apply the tools and Six Sigma problem solving approach than the engineering technology students. This could be due to a variety of factors, including the inexperience of the undergraduate engineering technology 
students with problem solving on real-world projects, their lack of knowledge of statistics, and the lack of Black Belt and graduate student mentors to help them better learn the tools. It is critical that experienced mentoring is provided for the students when solving a real-world unstructured problem. It was extremely difficult for the instructor to be the only Black Belt mentor, and subsequently did not provide enough coaching for the students. The instructor decided to slightly change the instructional strategy around the real world Six Sigma project during the Spring 2007 semester. Instead of the students working on a "from scratch" new real world Six Sigma project, the instructor used a prior project from the graduate level Six Sigma course. She provided the background to the problem, and the data that was collected. Although the students don't get the interaction with a real project sponsor and customers, they do get the advantage of real data and an actual problem that needed to be solved. This provides time to prepare the students in the foundations of statistics, and the DMAIC methodology, while providing an "almost" nuts to bolts real world Six Sigma project experience. Future results of the Spring 2007 semester with the revised instructional strategy related to the Six Sigma project will be presented in a future paper.

\section{References:}

[1] Instructor, Total Quality Improvement, ESI 5227, Course Syllabus, University of Central Florida, 2005.

[2] Instructor, Quality Assurance, ITEC 4300, Course Syllabus, University of Central Florida, 2006.

[3] National Academy of Engineering, The Engineer of 2020, Visions of Engineering in the New Century, The National Academies Press, Washington DC, 2004

[4] National Leadership Council for Liberal Education and America's Promise. College Learning for the New Global Century. American Association of American Colleges and Universities, 2007 